\title{
A magyar nyelvú hajózási szakirodalom rekonstrukciója az Európai Unió Duna Régió Stratégiájának tükrében
}

\author{
A magyar nyelvư nyomtatott hajózási szakirodalom kezdetektől tör- \\ ténő feltárása megoldásra váró feladat. A tanulmányban a témával \\ kapcsolatos eddigi, könyvtár- és információtudományi fókuszú - el- \\ sősorban a hálózati információforrásokra rámutató - munka szerves \\ folytatásaként bemutatásra kerül egy hosszú távú, a vizsgálatba bevo- \\ nandó gyüjteményeket és a korszakhatárokat tekintve is több lépcsős,
} komplex kutatási terv.

DOI 10.24.228/KTSZ.2018.3.5

\section{Dr. habil. Kiszl Péter \\ intézetigazgató, tanszékvezető egyetemi docens \\ ELTE BTK Könyvtár- és Információtudományi Intézet \\ Információtudományi Tanszék \\ e-mail: kiszl.peter@btk.elte.hu}

\section{BEVEZETÉS}

A hajózás ősidők óta a Duna menti népek életének szerves része. A vasútnál és a közútnál is régebbi közlekedési alágazat Magyarország jövője szempontjából sohasem lesz elhanyagolható tényező.

Az Eötvös Loránd Tudományegyetem Bölcsészettudományi Kar (ELTE BTK) Könyvtár-és Információtudományi Intézetében az Európai Unió Duna Régió Stratégiájához (EU DRS) ${ }^{1}$ igazodva - annak kulturális akciótervét erösítve - célul tűzték ki a jelentősebb magyarországi közgyüjtemények állományának elemzé-

1 EU Strategy for the Danube Region: http://ec.europa.eu/regional_ policy/en/policy/cooperation/macro-regional-strategies/danube [2018. 03. 06.] és Danube Region Strategy: http://danube-region. eu [2018. 03. 06.] se után egy annotált hajózási szakbibliográfia készítését. Ezt követné a hajózástörténeti öszszefüggések feltárása, a korabeli könyvgyüjtemények lehetőség szerinti azonosítása stb. Kiindulásképp az 1561 óta tervszerüen gyarapított, elsőként (1780) és több időszakban is kötelespéldány joggal bíró ELTE Egyetemi Könyvtár és Levéltár állományát vesszük górcső alá, majd az Országos Széchényi Könyvtár (OSZK), a Budapesti Müszaki és Gazdaságtudományi Egyetem Országos Müszaki Információs Központ és Könyvtár (BME OMIKK), továbbá a Magyar Müszaki és Közlekedési Múzeum (MMKM) gyüjteménye kerülhet sorra. Önálló projektként jelentkezik a Magyar Hajózási Részvénytársaság (MAHART) - ma már nem létező - Szakkönyvtára történetének kibontása. A mai közlekedési tájékoztatásügyben - az ágazat jelenlegi hazai gazdasági súlyához igazodva - a hajózás csekély jelentőséggel 
bír, inkább szabadidős és történeti irányultságú új kiadványok jelennek meg, tudományos igényüek elvétve. Nem mindig volt ez így. A hivatásos hajózás korábbi hazai fénykorát felidézve könyvtári gyökereink rendszerezett bemutatása ezért is kötelességünk.

\section{A KUTATÁS ELÖZMÉNYEI}

A korábbi kutatások során már foglalkoztam a magyar online hajózási szakirodalom feltárásával az ELTE BTK Könyvtár- és Információtudományi Intézete égisze alatt. ${ }^{2}$ Fontos eredménye az eddigi vizsgálatoknak a - hosszú évtizedek óta sajnálatos módon alulreprezentált - hajózási szakirodalom gyarapítása mellett a meglévő dokumentumforrások korszerü információszolgáltatási elveknek megfelelő rendszerezése, kategorizálása, elemzése. Ezzel párhuzamosan a hajózással kapcsolatos tudományos ismeretterjesztés is deklarált küldetésünk. ${ }^{3}$

A 2010-ben megjelent Hálózati révkalauz könyv - címével ellentétben - nem kizárólagosan a webes tartalmakra világít rá. Történeti szála (pl. a Duna Bizottság létrejötte, a MAHART-kronológia és az állami nagyvállalat egykori érdekeltségeinek egyedülálló, grafikusan ábrázolt családfája) mellett felvonultatja a téma befogadásához feltétlenül szükséges szakzsargon közérthető ismertetését (pl. vízállás, Hajósoknak szóló hirdetmények - HSZH), a vízi közlekedés aktuális problémáinak magyarázatát (pl. a Duna hajózhatósága, képzések), és kitér a közgyüjtemények (pl. Magyar

2 Kiszl Péter: „Navigare necesse est...” Magyarországi hajózási információforrások az interneten. = Tudományos és Müszaki Tájékoztatás 55. évf. 2008. 5. sz. 207-220. p. és Kiszl Péter: Hálózati révkalauz. Magyarországi hajózási információforrások az interneten. Eger, EKF Líceum Kiadó. 2010.

3 Újabb aranykorát éli a hazai hajózás. Hirado.hu 2017. július 23.: https://www.hirado.hu/2017/07/23/a-hazai-hajozas-is-ujabbaranykorat-eli [2018. 03. 06.] és M1 Médiaklikk, 2017. július 23.: https://nava.hu/id/3170965 [2018. 03. 06.] Összefoglaló a Kiszl Péter és a Spányik Gábor közreműködésével készült műsorról az ELTE BTK KITI blogján: http://elte-lis.blogspot.hu/2017/07/ahajozasi-informacioforrasokrol-kiszl.html [2018. 03. 06.] A hajózás sajnos ritkán kerül a képernyöre, a közelmúltból idézhető másik felvétel pl.: FIX TV Fix Magazin, Hajózás a Dunán. 2016. március 22.: https://www.youtube.com/watch?v=LC76ecfnsEk\& [2018. 03. 06.] (interjú Mészáros Tiborral).
Digitális Képkönyvtár - MDK, Magyar Nemzeti Levéltár - MNL, Nemzeti Audiovizuális Archívum - NAVA) - változatos hordozójú állományainak értékelésére, valamint eddig még nem publikált statisztikák (pl. a volt Nemzeti Közlekedési Hatóság - NKH lajstromadatai) közlésére is.

A hálózaton elérhető információforrások szisztematikus számbavétele után, világosan körülhatárolható, további kutatási témaként jelentkezik a hagyományos (nyomtatott), kulturális örökségünk szempontjából is értékes, hajózási (és a szorosabban kapcsolódó vízügyi, környezetvédelmi stb.) dokumentumok mélyebb, tudományos igényü feldolgozása. Ez Magyarország részéről erősíthetné az Európai Unió Duna Régió fejlesztését célzó kulturális törekvéseit, a Duna Régió Stratégia hazai megvalósítását. ${ }^{4}$

Mivel a magyar hajózás érdemben a Dunára koncentrál, áttekintettük a Duna Bizottság - az egyetlen, 1954 óta budapesti székhellyel működő államközi szervezet - 1856 óta müködő könyvtári állományát. Megjegyzendő, hogy a krími háborút lezáró párizsi békeszerződés hívta életre az Európai Duna Bizottságot, és születtek meg a vonatkozó publikációk, ${ }^{5}$ de a testület jellegéből, küldetéséből adódóan, tervezett kutatásunk témájában számottevő előzmény nem áll rendelkezésre. A német, orosz és francia nyelvü kiadványok jellemzően nautikai, hidrológiai, statisztikai stb. irányultságú saját összeállítások. A világ nagyobb nemzeti könyvtárainak (pl. British Library, Bibliothèque Nationale de France, Library of Congress) katalógusaiban végzett magyar vonatkozású kereséseink sem hoztak meglepő eredményeket: a találatok túlnyomó része szépirodalom, almanach, visszaemlékezés, hadtörténet vagy térkép, navigációs anyag.

A magyarországi hajózási szakirodalomnak szélesebb körü összefoglalása gyakorlatilag

4 Duna Régió Stratégia: http://dunaregiostrategia.kormany.hu [2018. 03. 06.]

5 Catalogue of Publications of the Danube Commision as of 27 February 2017. Budapest. https://goo.gl/Rj3SZt [2018. 03. 06.] 


\section{Hajózási irodalomkutatás}

nem létezik: a rendszerváltás után kiadott müvek egy-egy szűkebb kérdéskörrel, így a hajózás történetével, ${ }^{6}$ néprajzi vetületeivel, ${ }^{7}$ neves személyekkel, ${ }^{8}$ fogalmak értelmezésével $^{9}$, területfejlesztéssel ${ }^{10}$ foglalkoznak vagy ismeretterjesztő szándékkal ${ }^{11}$ készültek. A tankönyvek ${ }^{12}$ mellett legfrissebb kiadványként A magyar Duna-tengerhajózás története című terjedelmes monográfiára ${ }^{13}$ és az osztrák Via Donau kötetének magyar adaptációjára, A dunai hajózás kézikönyvére ${ }^{14}$ utalhatunk. Több - kortörténeti értékkel bíró - visszaemlékezés ${ }^{15}$ is napvilágot látott. A szakmai konferenciákon elhangzott elö-

6 Pl.: Hámori Péter: A magyar hajózás képes története. Budapest, Nemzeti Tankönyvkiadó. 2009.; Horváth József: A „Nautica”. A fiumei M. Kir. Állami Tengerészeti Akadémia története. Budapest, Ha-Jós Bt. 1999.; Marczis Ervin: 100 éves a magyar állami hajózás. Budapest, MAHART. 1994. és Margitay-Becht András: A Leitha monitor és a többiek. Zabolátlan hajózás-történeti barangolás térben és időben egy vénséges vén dunai hadihajó ürügyén. Budapest, Hadtörténeti Intézet és Múzeum - Petit Real Könyvkiadó. 2007. (A HM Hadtörténeti Intézet és Múzeum kiadványai)

7 Pl.: Paládi-Kovács Attila főszerk.: Magyar néprajz. 2. köt. Gazdálkodás. Vízi szállítás. A fej. írta Gráfik Imre. Közread. az MTA Néprajztudományi Kutatóintézete. Budapest, Akadémiai Kiadó. 2001. 974-1020. p.

8 Pl.: Horváth Imre: Balatoni Hajózási Rt. hajósai. Történetünk 1846-tól napjainkig. Siófok, Balatoni Hajózási Rt. 2005.

9 Pl.: Vass Ödön: Hajózási értelmező szótár hivatalos és kedvtelési hajósoknak, tengerészeknek. Budapest, Alapítvány a Hajósoktatásért. 2006.

10 Pl.: Dövényi Zoltán - Hajdú Zoltán összeáll.: A magyarországi Duna-völgy területfejlesztési kérdései. 1-2. köt. Budapest, MTA. 2002. (Magyarország az ezredfordulón. Stratégiai kutatások a Magyar Tudományos Akadémián. IV., A területfejlesztési program tudományos alapozása) és Rechnitzer János szerk. és összeáll.: A Duna a magyar területfejlesztésben. Almanach. 2009. Pécs, MTA Regionális Kutatások Központja. 2009.

11 Pl.: Rappai Zsuzsa szerk. és összeáll.: Így utaztunk anno. Hajózás. Budapest, Kossuth Kiadó. 2007. 136-167. p.

12 Pl.: Hadházi Dániel - Hargitai L. Csaba - Horváth Gábor Simongáti Győző: Hajózás. I. Egyetemi tananyag. Budapest, Typotex Kiadó. 2012. http://www.tankonyvtar.hu/hu/tartalom/ tamop412A/0018_Hajozas_1 [2018.03.06.]

13 Hadnagy Gábor főszerk.: A magyar Duna-tengerhajózás története. Budapest, Magyar Tengerészek Egyesülete. 2017.

14 Rafael Róbert - Bálint Ágnes - Jármy Tibor szerk.: A dunai hajózás kézikönyve. Ford. Szombathy Csaba - Varga Lajos. Budapest, Rádiós Segélyhívó és Infokommunikációs Országos Egyesület. 2013. http://dhk.rsoe.hu [2018. 03. 06.]

15 Pl.: Pálfi Sándor: Hajózni muszáj... Életem a hajózás történelmi múltjában. Szeged, Bába Kiadó. 2010. vagy Bikkes István - Nagyszékely István: Hajós legendák - legendás hajósok. Budapest, Fluvius Kft. 2013. adások nyomtatott vagy elektronikus tanulmánykötet formájában történő terjesztése viszont nem elterjedt gyakorlat. ${ }^{16}$

1997-ből külön is érdemes kiemelni a Magyar Tudományos Akadémia (MTA) távlati kutatási terveinek kialakítására megfogalmazott hét vitapontja (Duna-program) közül az utolsót, amely a szaktudományok új szintézisét sürgeti. „A dunai együttmüködés hetedik célja: új típusú szakmai fórumot teremteni a tudományos értelmiségnek"17 - írja az akkori akadémiai elnök, Glatz Ferenc. A figyelemfelhívás ezzel egybecseng: interdiszciplináris fórumot és együttmüködő közösséget teremteni a hajózási szakirodalmat feltáró törekvéseknek.

\section{A KUTATÁS FŐ CÉLKITÜZÉSE}

Ismereteink korlátozottak a kezdetektől a hajózáshoz kötődő magyar nyelvü kiadványok számáról, bibliográfiai adatairól, tartalmi jellemzőiről, szerzőiről stb. A közlekedéstudományi gyűjtőkörű intézmények gyakran egymástól elszigetelten vagy gyér kooperációval müködnek, és az érintett szakdokumentumok körével még nem jutottak el az online feltárásig, digitalizálásig. ${ }^{18}$ Ennek megfelelően a tervezett kutatás fókuszai:

1. A magyar nyelvü hajózási szakirodalom bibliográfiai szintű regisztrálása.

2. A dokumentumállomány tartalmi vizsgálata.

3. A szakszerzők munkásságának felgöngyölítése.

4. A tulajdonosi bejegyzésekből, ex-librisekből és tulajdonbélyegzőkből a meghatározó könyvgyüjtemények azonosítása.

5. Összefüggések keresése, egy adott korszak hajózási problémakörének felvázolása.

6. A fent említett feladatok hatásainak rávetítése a mai viszonyokra (ld. DRS) a kulturá-

16 Utalhatunk itt pl. a MAHOSZ szervezésében, az EU Interreg DANTE program (http://www.interreg-danube.eu/approvedprojects/dante [2018. 03. 06.]) keretében 2018. január 18-án Budapesten tartott Nemzetközi Hajózás Szakmai Kongresszusra: http:// www.hajoskongresszus.hu [2018. 03. 06.]

17 Glatz Ferenc: Hét pont a Dunáról. = Ezredforduló. 1. évf. 1997. 1. sz. 28. p.

18 Vö. Közgyüjteményi Digitalizálási Stratégia 2017-2025. https:// goo.gl/jyQqj5 [2018. 03. 06.] 


\section{Hajozzási irodalomkutatás}

lis identitás erősítése érdekében, hiszen „a Duna régió helyi közösségei saját értékeik, kultúrájuk mentén szerveződve találják meg helyüket Európa térképén." ${ }^{19}$

\section{A KUTATÁSBA BEVONANDÓ KÖNYVTÁRAK, GYÜJTEMÉNYEK}

Első lépésként az ELTE Egyetemi Könyvtár és Levéltár állományából, a könyvekre vonatkoztatva tervezzük a gyüjtést a kezdetektöl 1949es időhatárral. A választás azért erre a gyüjteményre esett, mert:

1. az intézményi háttérből adódóan kedvezőek a kutatási lehetőségek;

2. a baloldali fordulatig a könyvtár enciklopédikus gyüjtőkörrel rendelkezett;

3. az 1561-ben alapított állománya hazai és európai viszonylatban is egyedülálló;

4. a formai és tartalmi feltárás hiányosságai miatt igazi könyvtárszakmai kihívást jelent a dokumentumok visszakeresése.

Az 1-3. ábrák ízelítőt adnak az ELTE Egyetemi Könyvtár és Levéltárban megbúvó kincsekről.

$\mathrm{Az}$ Országos Széchényi Könyvtár, Magyarország nemzeti könyvtára nélkülözhetetlen támpontot nyújthat a hazai könyves kultúra teljességre törekvő, 4 millió kötethez közelítő egyben tartásával, szolgáltatásával. Az 1986 előtti művek egy része csak a helyben használható cédulakatalógusban érhető el, online rendszerben még nem böngészhető. A Budai Várban őrzött könyvek mellett gazdag (kb. 400000 évfolyamnyi) folyóiratállományában olyan - még sok mai hajós számára is ismert periodikumok is fellelhetők mint:

- a Magyar Hajózás, a Magyar Hajózási Részvénytársaság egykori üzemi lapja összes (41) évfolyama 1963-tól egészen 2003-ig. Sajnos, néhány hiány is fennáll, az 1992. évből a 10. szám, 1996-ból az 1-3. szám és a 7. szám, 1999-ből az 5. szám nem található meg az

19 Duna kézikönyv. Duna Programiroda. Budapest, Studio Metropolitana. 2010. 16. p.
1. ábra: Szerelmey Miklós: Balaton-album címü müvének (Pest, Emich Gusztáv Nemzeti Könyvkereskedése. 1848.) címlapja az ELTE Egyetemi Könyvtár és Levéltár állományából (jelzet: Hd 5482 Rar. Hung. 478)

$$
\text { Rar.joung } 478 \quad H d 5782
$$

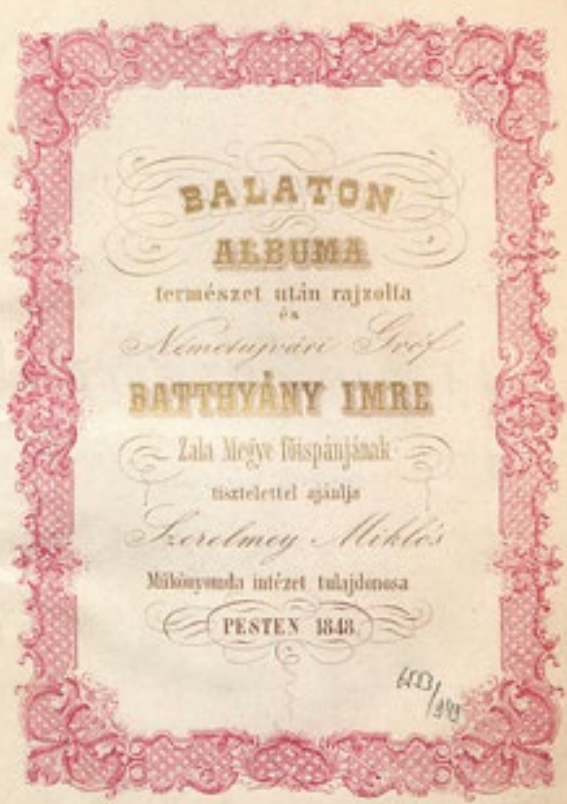

OSZK-ban. ${ }^{20}$ (Ugyanezzel a címmel korábban is jelentek meg lapok: Magyar Hajózás, 1898-1918 és Magyar Hajózás. Hajózási és kikötői folyóirat, 1947-1948, Közlekedésügyi Minisztérium Hajózási Főosztálya.)

- a Viziközlekedés 1972-1990 közötti, 19 évfolyamot megélt MAHART-kiadvány (az OSZK-ban hiányzik az 1973. évi 3. szám). ${ }^{21}$

- a Hajózási szakirodalmi tájékoztató, ${ }^{22}$ a MAHART és az Országos Müszaki Információs

20 OSZK katalógus. Magyar Hajózás: http://nektar.oszk.hu/ida/ index.php?id=81711 [2018. 03. 06 .

21 OSZK katalógus. Víziközlekedés: http://nektar.oszk.hu/ida/index. php?id=42713 [2018. 03.06.]

22 OSZK katalógus. Hajózási szakirodalmi tájékoztató: http://nektar. oszk.hu/ida/index.php?id=42017 [2018. 03. 06.] 


\section{Hajózási irodalomkutatás}

2. ábra: Reitter Ferenc: Duna-szabályozás Buda és Pest között címú múvének (Pest, Pollák Testvérek. 1865.) címlapja az ELTE Egyetemi Könyvtár és Levéltár állományából (jelzet: Cd 2421)

\section{2421}

DUNA-SIABÁLYOZÁS

Buda es Pest koxbtt

\section{PESTI HAJÓZÁSI- CSATORNA.}

A Csepelaciget s a soroksiri Dana-ág balpartjän

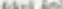

\section{ARMENTESITESE.}

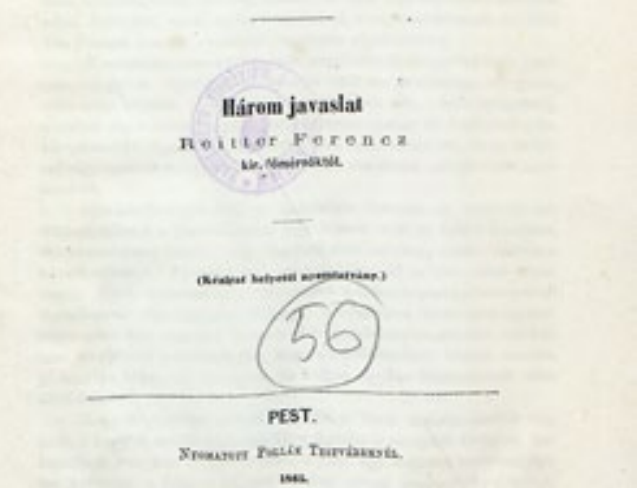

Központ és Könyvtár 1983-1995 között terjesztett referálólapja.

Ennél a kör persze jóval bővebb (pl. Hajózási Hírlap, 1928-1944). Rövid felsorolással arra világítok rá, hogy az időszaki kiadványok repertóriumának elkészítése és/vagy digitalizálása még sok munkát igényel.

A Budapesti Müszaki és Gazdaságtudományi Egyetem Országos Müszaki Információs Központ és Könyvtár a nevében is szereplö két könyvtár (BME és OMIKK) 2001-es összevonásával jött létre, így a müszaki irányultságú gyüjtőkörében hajózási témakörök is megjelennek. A BME Vasúti Jármüvek, Repülőgépek és Hajók Tanszék szakirodalmi támogatása, illetve az OMIKK korabeli - fentebb már
3. ábra: Domanovszky Sándor: Duna-

Feketetengeri kereskedelmi hajózásunk múltjáról címü müvének (Tengertudományi értekezések, Budapest, Magyar Adria Egyesület „Êlet” Irodalmi és Nyomda Részvénytársaság. 1918.) címlapja az ELTE Egyetemi Könyvtár és Levéltár állományából (jelzet: Cd 2622)

\section{TENGERTUDOMANYI ERTEKEZESEK}

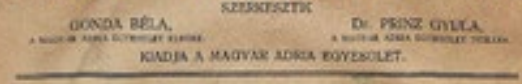

\section{Duna-Feketetengeri}

kereskedelmi hajózísunk multjáról.
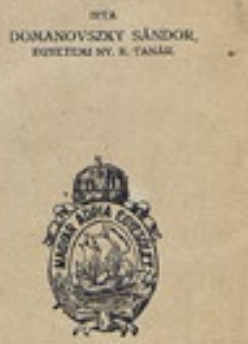

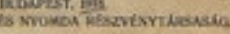

említett - témafigyelési szolgáltatásai miatt ugyancsak jelentékeny találati halmazra bukkanhatunk.

A felsőoktatási intézmények közül a győri Széchenyi István Egyetem Egyetemi Könyvtára emelendő ki, ahol az OSZK-ban hiányként jelzett 1996-os és 1999-es Magyar Hajózás számai is olvashatók. 2018. február 2-án 85 év - Történeti képek a magyar tengerhajózás évtizedeiről címmel, a Magyar Tengerészek Egyesülete (MATE) közremüködésével nyílt kamarakiállítás a könyvtárban. ${ }^{23}$

23 A magyar Duna-tengerhajózás elindításáról 85 évvel ezelőtt született döntés. M5. 2018. február 13.: https://www.mediaklikk.hu/ video/2018/02/13/a-magyar-duna-tengerhajozas-elinditasarol-85evvel-ezelott-szuletett-dontes [2018. 03. 06.] 
Az egykori Közlekedési Múzeum (ma: $M a-$ gyar Müszaki és Közlekedési Múzeum) tudományos szakkönyvtáráról 1996-ban publikált tanulmány szerint köteteik 9\%-a, míg folyóirataik $8 \%$-a vízi közlekedési témájú. ${ }^{24} \mathrm{Az}$ arányok azóta minden bizonnyal romlottak, de a vizsgálat itt is elengedhetetlen. Projektünk szempontjából az archívum darabjai (pl. menetjegyek, térképek, plakátok, prospektusok) kevéssé relevánsak. ${ }^{25}$

Az MTA Információs Központ és Könyvtár, az Országgyülési Könyvtár (OGYK), valamint további szakkönyvtárak és a Fővárosi Szabó Ervin Könyvtár (FSZEK) katalógusait is elemezni kívánom, az utóbbi Budapest Gyüjteménye a Magyar Hajózás 1970-1993 és 1997-2003 közötti, illetve a Víziközlekedés 1973-1983 és 1987-1990 közötti számait is őrzi. Amennyiben lehetőség adódik rá, magángyüjteményeket is szeretnék bevonni a kutatásba.

A különféle szakirodalmi adatbázisok sem kerülhetők meg, mint például a nyomtatott folyóiratok szkennelt tételeivel folyamatosan gyarapodó Arcanum Digitális Tudománytár (ADT), ${ }^{26}$ a Hungaricana ${ }^{27}$ vagy az OSZK - Országos Könyvtári Rendszer (OKR) fejlesztései hatására is - egyre bővülő hálózati tartalmai. ${ }^{28}$ $\mathrm{Az}$ Elektronikus Információszolgáltatás (EISZ) Nemzeti Program ${ }^{29}$ keretében elérhető - az ADT mellett elsősorban nemzetközi szakirodalom - kontrollálása is indokolt.

\section{A MAHART EGYKORI SZAKKÖNYVTÁRA}

Külön egységként kezelendő a MAHARTkönyvtár sorsának bemutatása. Az állomány-

\footnotetext{
24 Barkóczi Jolán-Tisza István: A Közlekedési Múzeum tudományos szakkönyvtára. In: A Közlekedési Múzeum Évkönyve 10. 18961996. Főszerk. Katona András. Szerk. Hüttl Pál. Budapest, Közlekedési Múzeum. 1996. 223-235. p.

25 Eperjesi László: Az archívum. In: A Közlekedési Múzeum Évkönyve 10. 1896-1996. Főszerk. Katona András. Szerk. Hüttl Pál. Budapest, Közlekedési Múzeum. 1996. 203-222. p.

26 ADT: https://www.arcanum.hu/hu/adt [2018. 03. 06.]

27 Hungaricana: https://hungaricana.hu/hu [2018. 03. 06.]

28 OSZK OKR: http://www.oszk.hu/okr-projekt [2018. 03. 06.]

29 EISZ: http://www.eisz.mtak.hu [2018. 03. 06.]
}

ról rendkívül hiányosak az információink. Egy biztos: a MAHART Apáczai Csere János utcai szakkönyvtárának 3142 db dokumentumát - a részleteket tartalmazó lista nélkül - 2003. november 28-án átadták a Magyar Hajózási Szakközépiskola és Szakiskola (ma: Budapesti Gépészeti Szakképzési Centrum Magyar Hajózási Szakgimnáziuma és Szakközépiskolája - BGC Magyar Hajózási SZG és $S Z K I)$ számára. ${ }^{30}$ A feltárás a mai napig nem történt meg, s éppen napjainkban indultak meg a tárgyalások a MMKM illetékeseivel a múzeumba való átszállítás lehetőségéről. A dokumentumállomány nagyobb részének sorsa így számunkra ismeretlen, a Közlekedési Múzeumba nem került. ${ }^{31}$ A Magyar Hajózási SZG és SZKI könyvtárostanárának közlését idézzük: „...idősebb hajós kollégáktól azt az információt kaptam, hogy az anyag nagyobbik - ismeretlen összetételü - része egy újpesti raktárban került elhelyezésre, ahol a következő árvíz során megsemmisült."32 A Magyar Hajózás címü időszaki kiadványra visszatérve, a Magyar Hajózási SZG és SZKI MAHART-gyưjteményében megbújik az 1992. évi 10. szám és az 1999. évi 5. szám (több példányban is) - a Széchenyi István Egyetemmel és a FSZEK-kel karöltve meg is oldható az OSZK-ból hiányzó darabok pótlása, amellyel teljessé válhat a MAHARTlap portfoliója.

\section{SZAKMAI EGYÜTTMÜKÖDÉSEK}

A szakmai program elsősorban anyaggyüjtési szakaszában egyetemi hallgatók és doktoranduszok is részt vesznek, illetve felvetödik a témakör és az összegyüjtött anyagok speciálkollégiumi keretek között történő további vizsgálatának lehetősége. Kikerülhetetlen irodalomtörténész, könyvtáros, mérnök, hajózási, történész stb. szakértők és a szakmai szervezetek (pl. Közlekedéstudományi

30 Átadás-átvételi jegyzőkönyv a MAHART szakkönyvtár állományának átadásáról. Budapest, 2003. november 28. Átadó: Garadnai András (MAHART). Átvevő: Árvay Miklós (Magyar Hajózási Szakközépiskola és Szakiskola). [Másolat az átvevő irattárából.]

31 Benei Bernadett muzeológus (MMKM) 2018. február 15-én kelt Kiszl Péternek írt e-mail üzenete.

32 Keresztessy Csaba könyvtárostanár (Magyar Hajózási SZG és SZKI) 2018. február 16-án kelt Kiszl Péternek írt e-mail üzenete. 
Egyesület Hajózási Tagozat, Magyar Hajózási Országos Szövetség - MAHOSZ, Magyar Hajózásért Egyesület - MHE, MATE) bevonása a projektbe.

A magyar hajózási szakirodalom feltérképezése megjelenik az ELTE Irodalomtudományi Doktori Iskola Könyvtártudomány doktori programjának témakínálatában: „A makroregionális EU Duna Stratégia - elsősorban kulturális akcióterveinek, szellemi örökségvédelmi törekvéseinek, térségszervező hatásainak - támogatása a magyar hajózási történeti gyökerek széles körü közzétételével: formai és tartalmi elemzés, annotált szakbibliográfia készítése, gyüjtemények azonosítása tulajdonosi bejegyzések alapján, további öszszefüggések feltárása." ${ }^{33}$

\section{A PROJEKT ÜTEMEZÉSE}

A forrásközpontú kutatási program hosszú távú (5 éven túl) elvégezhető feladatokat nevesít:

1. Anyaggyüjtés;

2. Annotált bibliográfia összeállítása;

3. A dokumentumok tartalmi feltárása;

4. A szerzők életrajzi adatainak kutatása;

5. Possessor bejegyzések, ex-librisek, tulajdonjelzések elemzése;

33 Országos Doktori Tanács. Témakiírás. Kiszl Péter: A magyarországi hajózási szakirodalom rekonstrukciója: https://doktori.hu/ index.php?menuid=195\&lang=HU\&tk_ID=142060 [2018. 03. 06.]
6. Részeredmények szükség szerinti disszeminációja;

7. Összefüggések feltárása;

8. Eredmények disszeminációja;

9. Az elméleti és empirikus eredmények alapján monográfia összeállítása és internetes tartalomszolgáltató felület közzététele, majd folyamatos karbantartása.

A tervezett munkák intenzitása nagyban függ a rendelkezésre álló anyagi (pl. pályázati) lehetőségektől és az együttmüködő partnerek körétől.

Időhatárként több változatban lehet gondolkodni. Az ELTE Egyetemi Könyvtár és Levéltára vonatkozásában már jeleztem az 1949-es dátumot, de a teljes kutatási spektrumot tekintve akár szóba jöhet a rendszerváltás is, mint kiterjesztett horizont. Mindezt a rendelkezésre álló kapacitások határozzák majd meg.

\section{VÁRHATÓ EREDMÉNYEK}

A munka - diszciplínákon átívelő - hazai és nemzetközi figyelemre számít: a történet- és az irodalomtudomány képviselőin túl, a hajózási szakma mellett a könyvtári tájékoztatás igényeinek kielégítése a cél, továbbá a hajózási dokumentumok, információforrások felkutatásán, feldolgozásán és akár egy repozitóriumi platformon történö szolgáltatásán keresztül szorosabb közösségbe kovácsolni a magyarországi hajózás múltja, jelene és jövője iránt érdeklődőket.

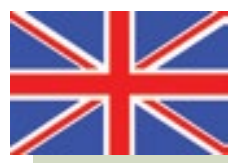

\section{The reconstruction of the hungarian literature of shipping in light of the european union's danube region strategy}

The exploration of the Hungarian language printed literature of shipping is a task to be solved. In this paper, as an organic continuation of my recent research
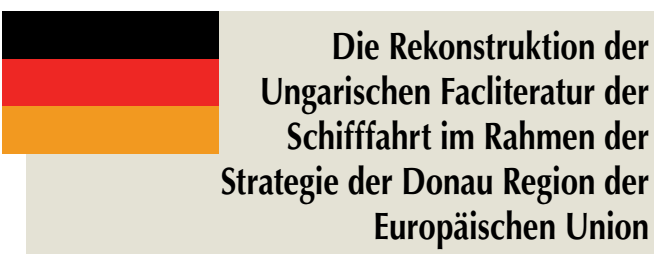

Die Erforschung der in ungarischer Sprache gedruckten Literatur für die Schifffahrt ist eine Aufgabe, die es zu lösen gilt. In dieser Arbeit stelle ich als eine or- 


\section{Hajózási irodalomkutatás}

of the topic focusing on library and information science - primarily on network information sources - I present a longterm, complex research plan, which will be realized in several steps taking into consideration the series of collections to be researched and the various periods they date from.

In line with the European Union's Strategy for the Danube Region - in fact reinforcing its cultural action plan -, in the Institute of Library and Information Science at the Faculty of Humanities and Social Sciences of the Eötvös Loránd University, an objective was set to create an annotated professional bibliography after the analysis of the holdings of major Hungarian public collections (and possibly private libraries), and subsequently to development related digital content services. Presentation of the history of the former MAHART Library is a standalone project. Our interdisciplinary commitment can be realized through a wide professional collaboration, and with the supportive co-operation of the representatives and organizations of several fields. ganische Fortführung meiner aktuellen Forschung zum Thema Bibliotheks- und Informationswissenschaft - die sich vor allem auf einheimischen Netzwerkinformationsquellen basiert - einen langfristigen, komplexen Forschungsplan vor, der in mehreren Schritten unter Berücksichtigung der zu erforschenden Sammlungen und der verschiedenen Perioden, aus denen sie stammen, durchgeführt werden kann.

Im Einklang mit der Strategie für den Donauraum der Europäischen Union - und zwar mit dem Ziel, ihren kulturellen Aktionsplan zu stärken - wurde im Institut für Bibliotheks- und Informationswissenschaft der Fakultät für Geistes- und Sozialwissenschaften der Eötvös-Loránd-Universität das Ziel gesetzt, nach der Analyse der Bestände der großen ungarischen öffentlichen Sammlungen (und möglicherweise privaten Bibliotheken) eine annotierte professionelle Bibliographie zusammenzustellen und später die anschließenden digitalen Inhaltsdienste zu entwickeln. Die Präsentation der Geschichte der ehemaligen MAHART-Bibliothek ist ein eigenständiges Projekt. Unser interdisziplinäres Engagement kann durch eine breite professionelle Zusammenarbeit und durch die unterstützende Zusammenarbeit der Vertreter und Organisationen mehrerer Bereiche realisiert werden. 